\title{
EFEKTIVITAS MODUL BERBASIS PROBLEM SOLVING UNTUK MENINGKATKAN KEMAMPUAN ANALISIS SISWA
}

\author{
Try Nesia Nurhemy ${ }^{1}$, Sutarno $^{2}$, dan Baskoro Adi Prayitno ${ }^{3}$ \\ ${ }^{1}$ Program Studi Magister Pendidikan Sains FKIP Universitas Sebelas Maret \\ Surakarta, 57126, Indonesia \\ nesia.nhesha@gmail.com \\ ${ }^{2}$ Program Studi Magister Pendidikan Sains FKIP Universitas Sebelas Maret \\ Surakarta, 57126, Indonesia \\ nnsutarno@yahoo.com \\ ${ }^{3}$ Program Studi Magister Pendidikan Sains FKIP Universitas Sebelas Maret \\ Surakarta, 57126, Indonesia \\ baskoro_ap@fkip.uns.ac.id
}

\begin{abstract}
Abstrak
Tujuan dari penelitian dan pengembangan ini adalah mengetahui keefektivan modul berbasis Problem solving untuk meningkatkan kekampuan analisis siswa. Metode yang digunakan untuk penelitian dan pengembangan sesuai dengan prosedur Borg and Gall yang dimodifikasi menjadi sembilan tahapan dengan menerapkan sintaks model pembelajaran Problem solving. Penelitian dan pengembangan ini menggunakan rancangan eksperimen one group pretest posttest design. Hasil penelitian dan pengembangan ini menyatakan bahwa modul berbasis Problem solving pada materi pencemaran lingkungan efektif meningkatkan kemampuan analisis siswa. Hasil uji Wilcoxon terdapat perbedaan antara nilai sebelum diberikan modul berbasis Problem solving dan sesudah diberikan modul dengan nilai probabilitas (p) sebesar 0,000 lebih kecil dari 0,05. Menurut hasil uji Wilcoxon dapat disimpulkan bahwa modul berbasis Problem solving efektif meningkatkan kemampuan analisis pada materi pencemaran lingkungan
\end{abstract}

Keywords: Learning module, problem solving learning, problem solving-based learning module, and analytical thinking ability

\section{Pendahuluan}

Biologi merupakan salah satu bagian dari sains, sebagai bagian dari proses pendidikan yang memiliki peran besar dalam pengembangan individu. Sains pada hakikatnya memiliki dua dimensi yaitu sains sebagai produk dan sains sebagai proses. Sains sebagai produk dapat berupa pengetahuan yang berasal dari bahan ajar, makalah ilmiah, buku teks, artikel ilmiah, dan lain-lain. Produk nyata sains adalah konsep yang teruji kebenarannya, selain itu dapat berupa fakta, teori, prinsip, dan hukum (Tohaarudin, et al., 2011). Sains sebagai proses atau metode penyelidikan (inquiry methods) meliputi cara berpikir, sikap, dan langkah kegiatan saintis untuk memperoleh produk sains (Fatonah \& Prasetyo, 2014)

Kemampuan berpikir sangat penting dan dibutuhkan setiap individu dalam mengatasi berbagai masalah (Mamu, 2014). Salah satu kemampuan berpikir adalah berpikir tingkat tinggi (high order thinking). Berpikir tingkat tinggi merupakan operasi kognitif yang dibutuhkan pada proses berpikir (Zannah, 2013). Berpikir tingkat tinggi melibatkan kemampuan menganalisis informasi untuk menentukan masalah, mengevaluasi masalah, dan kemudian mampu menciptakan solusi terhadap permasalahan tersebut (Chinedu \& Kamin, 2015). Kemampuan analisis 
digunakan untuk memeriksa dan mengurai informasi, memformulasikan masalah, serta memberikan langkah penyelesaian dengan tepat (Cabanillapedro, Acob-navales, \& Josue, 2013). Berdasarkan TIMSS tahun 2013, hasil rata-rata skor siswa Indonesia berada pada peringkat 38 dari 42 negara dengan skor rata-rata 386 dari skor tertinggi 613. . Data ini menunjukkan lemahnya kemampuan berpikir siswa Indonesia, maka diperlukan upaya untuk meningkatkan kemampuan berpikir siswa (Marini, 2014). Fakta lain, kemampuan analisis siswa di Indonesia tergolong rendah, berdasarkan data dari Mckinsey Indonesian's Today dan rangkuman dari Kementerian Pendidikan tahun 2012 bahwa hanya $5 \%$ pelajar Indonesia yang memiliki kemampuan berpikir analisis (Rahmawati, et al., 2012).

Rendahnya kemampuan analisis siswa juga terlihat pada observasi di SMA Negeri 8 Surakarta. Siswa kurang dilatih untuk mengidentifikasi suatu peristiwa atau permasalahan, sehingga siswa tidak mampu untuk menemukan penyebab dari permasalahan yang terjadi. Hal tersebut menunjukkan bahwa siswa tidak terbiasa menggunakan data dan fakta untuk membantu pemecahan masalah, mencari solusi berdasaran penyebab masalah yang ditemukan, dan menerapkan solusi yang ditemukan. Ketiga hal tersebut merupakan bagian dari indikator kemampuan analisis.

Berdasarkan penelitian Maghfiroh (2011), peningkatan nilai kemampuan analisis siswa berhubungan dengan peningkatan hasil belajar kognitif siswa, sebab kemampuan analisis termasuk dalam ranah kognitif. Hubungan antara kemampuan analisis dan hasil belajar siswa juga berdampak di SMA Negeri 8 Surakarta. Rendahnya kemampuan analisis siswa berdampak pada penguasaan materi biologi siswa pada materi pencemaran lingkungan.
Berdasarkan data nilai ulangan harian siswa kelas X MIPA SMA Negeri 8 Surakarta tahun 2013/2014 memperoleh rata-rata 61,73 sedangkan tahun 2014/2015 rata-rata yang diperoleh sebesar 65,11. Berdasarkan data tersebut dapat diketahui bahwa rata-rata nilai ulangan harian siswa belum memenuhi kriteria ketuntasan minimum (KKM) mata pelajaran biologi yaitu $\geq 68$.

Analisis bahan ajar di lapangan menggunakan indikator kemampuan analisis pada materi pencemaran lingkungan. Hasil yang diperoleh pada aspek tujuan sebesar 28,57\%, aspek materi sebesar $30,36 \%$, aspek kegiatan sebesar $35,71 \%$, dan aspek soal evaluasi sebesar 19,64\%. Berdasarkan data tersebut bahan ajar cetak yang digunakan di SMA Negeri 8 Surakarta menunjukkan kurang mengembangkan kemampuan berpikir analisis siswa, sehingga perlu dikembangkan bahan ajar yang mengakomodasi aktivitas yang dapat meningkatkan kemampuan berpikir analisis siswa.

Bahan ajar merupakan segala bentuk bahan yang dapat digunakan untuk membantu guru dalam melaksanakan kegiatan belajar mengajar. Salah satu bahan ajar yang biasa digunakan adalah modul pembelajaran. Hasil observasi di lapangan menemukan bahwa SMA Negeri 8 Surakarta tidak memiliki modul, pembelajaran menggunakan buku paket yang beredar di pasaran. Buku yang digunakan oleh guru dan siswa belum berdasarkan sintaks model pembelajaran tertentu yang dapat melatih kemampuan analisis siswa. Berdasarkan analisis data di lapangan, solusi yang dibutuhkan adalah pengembangan modul dengan aktivitas kegiatan yang sistematis dan sesuai dengan indikator kemampuan analisis yang ditingkatkan melalui model problem solving. 


\section{Metode Penelitian}

Pelaksanaan pembelajaran dilaksanakan berdasarkan perangkat pembelajaran yang disusun dengan menggunakan modul pembelajaran biologi berbasis problem solving. Uji coba dilakukan untuk mendapatkan data berkaitan dengan produk yang dikembangkan sehingga diketahui keefektifan dan keunggulan dari produk tersebut. Uji pelaksanaan lapangan modul berbasis problem solving pada materi pencemaran lingkungan menggunakan one group pretest posttest design menurut Prayitno, dkk. (2016) yang mengutip Sugiyono yang disajikan Tabel 1.

Tabel 1. One Group Pretest Posttest Design

\begin{tabular}{lll}
\hline $\mathrm{O}_{1}$ & $\mathrm{X}$ & $\mathrm{O}_{2}$ \\
\hline
\end{tabular}

Keterangan:
$\mathrm{O}_{1}:$ nilai pretest (sebelum diberi
perlakuan)
$\mathrm{O}_{2}:$ nilai posttest (setelah diberi
perlakuan)
$\mathrm{X}$ : perlakuan dengan menggunakan
modul berbasis problem solving

Pretes dan postes dilakukan untuk mengetahui dampak penerapan modul biologi berbasis problem silving. Deskripsi hasil uji pretes dilakukan untuk mengetahui kemampuan analisis siswa sebelum menggunakan modul edangkan hasil postes digunakan untuk mengetahui kemampuan analisis siswa setelah menggunakan modul. Uji keefektivan digunakan untuk menghitung peningkatan kemampuan analisis siswa dengan menggunakan teknik normalized gain atau sering disebut gain score. Gain terormalisasi adalah teknik analisis untuk mengetahui tingkat kenaikan hasil belajar siswa. Gain terormalisasi menurut Hake (1998) dapat dihitung dengan rumus berikut:

Skor posttest-skor pretest $<\mathrm{g}>=$

skor maksimal-skor pretest

Keterangan:

$\langle$ g $\rangle=$ gain ternormalisasi
Tabel 2. Kriteria Gain Ternormalisasi

\begin{tabular}{ll}
\hline Nilai $\langle\mathrm{g}\rangle$ & Kriteria \\
\hline$<\mathrm{g}>\geq 0,7$ & Tinggi \\
$0,7\rangle\langle\mathrm{g}\rangle \geq 0,3$ & Sedang \\
$\langle\mathrm{g}\rangle\langle 0,3$ & Rendah \\
\hline
\end{tabular}

Tabel 2 merupakan interpretasi nilai gain ternormalisasi menurut Hake (1998). Selain analisis deskriptif Ngain, uju lanjut digunakan untuk menentukan signifikansi peningkatan kemampuan berpikir analisis. Teknik analisis data uji lanjut dilakukan dengan menggunakan perangkat lunak, yaitu Paket Statistik Ilmu Sosial (SPSS). Perangkat lunak SPSS dipilih sebagai alat untuk menganalisa data dalam penelitian ini karena program memiliki kemampuan analisis yang cukup tinggi. Sebelum peneliti menggunakan teknik analisis data ini, ada persyaratan yang harus dipenuhi, sehingga peneliti diijinkan untuk menggunakan teknik analisis, yaitu uji normalitas data dan uji homogenitas data. Pengujian normalitas data tersebut menggunakan uji Kolmogorov-Smirnov sedangkan pengujian homogenitas menggunakan uji Levene Statistic. Pengujian normalitas dan homogenitas data juga menggunakan perangkat lunak SPSS (Sudibyo, Jatmiko, \& Widodo, 2016). Setelah uji normalitas dan homogenitas hasil yang diperoleh adalah data tidak normal dan tidak homogen selanjutnya uji lanjut data dianalisis menggunakan uji statistik nonparametrik yaitu dengan uji Wilcoxon.

\section{Hasil Penelitian dan Pembahasan}

Kategorisasi peningkatan kemampuan berpikir analitis siswa dilakukan dengan menggunakan $\mathrm{N}$-gain (Hake, 1998). Menurut Hake (1998), kategorisasi dapat dikelompokkan menjadi tiga kategori, yaitu kenaikan kategori tinggi, sedang, dan rendah yang masing-masing bergantung pada pencapaian nilai $\mathrm{N}$-gain. Deskripsi data 
kemampuan analisis sebelum dan

Tabel 3. sesudah diberikan modul disajikan pada

Tabel 3. Deskripsi Nilai Kemampuan Analisis

\begin{tabular}{llllll} 
Jenis Tes & & & & & \\
& Jumlah Siswa & Mean & Standar Deviasi Minimum & Maksimum \\
\hline Pretes & 27 & 45.38 & 10.01 & 25 & 65.6 \\
Postes & 27 & 78.02 & 6.97 & 65.6 & 87.5 \\
\hline
\end{tabular}

Berdasarkan Tabel 3 dapat dilihat sebelum diberikan modul memiliki rerata kemampuan analisis sebesar $45,38 \%$ dengan standar deviasi 10,01, memiliki nilai minimum 25 serta nilai maksimum 65,6 . Nilai mean pada pembelajaran dengan modul sebanyak 78,02 dengan standar deviasi 6,97, memiliki nilai minimum 65,6 dan nilai maksimum 87.5. Peningkatan nilai kemampuan analisis dihitung menggunakan rumus $N$-gain ternormalisasi. Hasil perhitungan $\mathrm{N}$-gain ternormalisasi diperoleh rerata dari 27 siswa sebesar 0,6. Menurut kriteria Hake (1998) termasuk dalam kategori sedang. Langkah selanjutnya adalah uji prasyarat sebelum dilakukannya uji lanjut( Wilcoxon). Ringkasan hasil uji prasyarat dan uji lanjut dapat dilihat pada Tabel 4.

Tabel 4. Ringkasan Hasil Analisis Uji Prasyarat dan Uji Lanjut

\begin{tabular}{llllll}
\hline No. & Uji & Jenis Uji & Hasil & $\begin{array}{l}\text { Keputusa } \\
\mathbf{n}\end{array}$ & Kesimpulan \\
\hline 1. & Normalitas & Kolmogorov-Smirnov & $\begin{array}{l}\text { Sig pretes=0,2 } \\
\text { Sig postes }=0,007\end{array}$ & $\begin{array}{l}\mathrm{H}_{0} \\
\text { diterima }\end{array}$ & data tidak normal \\
& Levene Statistic & Sig 0.049 & $\begin{array}{l}\mathrm{H}_{0} \text { ditolak } \\
\mathrm{H}_{0} \text { ditolak }\end{array}$ & $\begin{array}{l}\text { data } \\
\text { homogen tidak }\end{array}$ \\
2. & Homogenitas & Wilcoxon & $\begin{array}{l}\mathrm{t}_{\text {hitung }}=-4,544 \\
\mathrm{p}=0,000\end{array}$ & $\mathrm{H}_{0}$ ditolak & $\begin{array}{l}\text { Hasil tidak sama } \\
\text { (ada beda) }\end{array}$ \\
3. & Hasil Pretes-Postes & & & & \\
\hline
\end{tabular}

Berdasarkan Tabel 4 hasil analisis nilai pretes dan postes siswa diketahui bahwa uji normalitas menggunakan uji Kolmogorov-Smirnov dengan nilai $\alpha=0,05$. Taraf signifikansi yang diperoleh sebesar 0,2 untuk nilai pretes, keputusan $\mathrm{H}_{0}$ diterima kaarena lebih besar dari nilai $\alpha=0,05$. Taraf signifikansi untuk nilai postes adalah 0,007 , keputusan $\mathrm{H}_{0}$ ditolak karena lebih kecil dari $\alpha=0,05$. Kesimpulan dari uji normalitas adalah nilai pretes dan postes siswa tidak terdistribusi normal. Uji homogenitas menggunakan uji Levene Statistic diperoleh hasil signifikansi sebesar 0,049 yang menunjukkan bahwa kurang dari nilai $\alpha=0,05$ dan keputusan $\mathrm{H}_{0}$ ditolak, artinya variansi setiap sampel tidak homogeny.
Data nilai pretes dan postes telah diketahui bahwa terdistribusi tidak normal dan tidak homogen. Uji lanjut yang digunakan adalah uji lanjut non parametrik yaitu uji Wilcoxon untuk mengentahui ada tidaknya perbedaan penggunaan modul pembelajaran Problem solving. Berdasarkan hasil uji Wilcoxon diperoleh thitung sebesar $-4,544$ dengan probabilitas $(p)$ sebesar 0,000 , sehingga $\mathrm{H}_{0}$ ditolak karena nilai $\mathrm{p}<0,05$. Melalui hasil uji lanjut tersebut dapat diketahui bahwa ada perbedaan nilai kemampuan analisis sebelum diberikan pembelajaran menggunakan modul berbasis Problem solving dan sesudah diberikan modul pembelajaran berbasis Problem solving. Kesimpulannya bahwa pembelajaran menggunakan modul berbasis Problem solving pada materi 
pencemaran lingkungan dapat meningkatkan nilai kemampuan analisis siswa. Modul berbasis problem solving lebih unggul dalam meningkatkan hasil belajar siswa (Wenno, 2010). Sejalan dengan penelitian Suhendri (2012) bahwa melalui problem solving dapat meningkatkan hasil belajar, karena siswa terlibat aktif dalam pembelajaran dan diberikan kebebasan untuk menggali informasi berdasarkan solusi permasalahan yang ditemukan sehingga materi lebih dipahami.

Modul berbasis problem solving pada materi pencemaran lingkungan efektif dalam meningkatkan kemampuan analisis siswa. Kemampuan analisis merupakan salah satu bagian dari keterampilan berpikir tingkat tinggi. Siswa dapat mengembangkan kemampuan berpikir tingkat tinggi melalui studi kasus dan artikel untuk menemukan permasalahan yang akan diselesaikan dalam pembelajaran. Melalui artikel memberikan alternalif lain bagi guru untuk tidak mengajar secara konvensioal. Hal ini dapat memberikan kesempatan siswa untuk memperoleh keterampilan berpikir selain pengetahuan konseptual. Dampak pengiring yang ditimbulkan adalah kasus-kasus dan artikel yang menarik membangkitkan rasa ingin tahu siswa, serta mengembangkan penalaran ilmiah dan komunikasi siswa (Hugerat \& Kortam, 2014). Penelitian lain yang mendukung dikemukanan oleh Tajudin \& Chinnappan (2016) bahwa berpikir tingkat tinggi dapat dilatihkan dengan memecahkan suatu masalah. Guru dituntut untuk memberikan lebih banyak ruang untuk mengembangkan kemampuan berpikir logis, sistematis dan kreatif untuk menghasilkan individu yang mampu berpikir logis, rasional dan mandiri.

Modul berbasis problem solving lebih efektif dibandingkan buku paket yang ada disekolah untuk meningkatkan kemampuan menganalisis siswa karena isi modul sudah tervalidasi dan kegiatan modul terarah berdasarkan indikator kemampuan analisis yang dijalankan berdasarkan sintaks model pembelajaran problem solving. Pembelajaran problem solving melatih siswa untuk mencari dan memecahkan masalah atau persoalan untuk mencapai tujuan pembelajaran (Sari \& Sisiloningsih, 2015). Sejalan dengan hasil penelitian Lestari (2013) bahwa pembelajaran menggunakan teori Bruner dapat membantu siswa untuk mengingat, memahami, mengolah serta mengemukakan seluruh pengetahuannya mengenai suatu konsep yang selanjutnya digunakan dalam penyelesaian masalah. Peningkatan kemampuan analisis siswa sebagai bukti bahwa keefektifan modul telah teruji. Pelaksanaan kegiatan modul pembelajaran problem solving diawali dengan memahami permasalahan, artinya modul ini sangat mengutamakan proses cara memperoleh pengetahuan agar siswa mampu berinovasi, mencipta, mendesain, dan merancang produk cara penyelesaian terhadap masalah yang ditemukan berdasarkan pengetahuan yang dimiliki (Risnawaty et al.,2016). Pada saat siswa memahami masalah, siswa harus tahu isi dari informasi yang disajikan, kemudian menentukan tujuan akhir yang akan dicapai (Yuan, 2013).

$$
\text { Permasalahan berdasarkan }
$$

informasi atau fakta yang dihadirkan kepada siswa memicu tumbuhnya ideide baru, sehingga siswa terdorong untuk merencanakan penyelesaian masalah. Kemampuan berpikir sangat fundamental pada proses pembelajaran. Masalah tidak dapat diselesaikan berdasarkan aplikasi langsung dari pengetahuan siswa yang dimiliki sebelumnya, sebaliknya masalah dapat diselesaikan ketika individu mampu mengkaitkan berpikir kritis dan kreatif. Pada kesempatan ini siswa ditantang untuk berpikir dan mengembangkan ideide terbaiknya sebagai solusi terhadap masalah sebagai wujud penerapan 
kemampuan berpikir tingkat tinggi (Chinedu \& Kamin, 2015).

Kegiatan modul berbasis problem solving dilanjutkan dengan menyelesaikan masalah. Tahap menyelesaikan masalah menurut Perveen (2010) dengan melakukan percobaan sebagai bentuk implementasi terhadap rancangan percobaan yang dibuat. Sejalan dengan penelitian Suminto (2015) bahwa pada tahap ini siswa mengumpulkan informasi yang sesuai dan melaksanakan eksperimen untuk mendapatkan penjelasan dan pemecahan masalah. Purnamasari, Suciati, \& Dwiastuti (2016) kegiatan menyelesaikan masalah sejalan dengan teori belajar Bruner bahwa belajar penemuan merupakan suatu proses pencarian pengetahuan secara aktif untuk mencari pemecahan masalah serta pengetahuan. Bruner mengemukakan hendaknya siswa belajar melalui partisispasi aktif siswa untuk memperoleh pengalaman dan melakukan kegiatan pengamatan dengan tujuan untuk menemukan pengetahuan.

Tahap lanjutan dari kegiatan modul berbasis problem solving adalah melakukan pengecekan, siswa akan melakukan pemeriksaan terhadap setiap langkah yang dilakukan beserta hasilnya agar sesuai dengan tujuan yang sudah ditetapkan (Perveen, 2010). Melakukan pengecekan dimaksudkan untuk melihat kembali tujuan yang sudah dicapai, jawaban yang sudah diketahui, dan adanya kesesuaian dengan solusi yang digunakan untuk menyelesaikan masalah (Gök \& Sýlay, 2010).

\section{Kesimpulan dan Rekomendasi}

Kesimpulan yang diperoleh dari hasil penelitian pengembangan modul berbasis problem solving pada materi pencemaran lingkungan yaitu.

1. Peningkatan nilai kemampuan analisis dihitung menggunakan rumus $N$-gain ternormalisasi. Hasil perhitungan $N$-gain ternormalisasi diperoleh rerata dari 27 siswa sebesar 0,6. Menurut kriteria Hake (1998) termasuk dalam kategori sedang.

2. Modul berbasis problem solving pada materi pencemaran lingkungan efektif meningkatkan kemampuan analisis siswa. Berdasarkan hasil uji Wilcoxon yang terdapat perbedaan antara nilai sebelum diberikan modul berbasis problem solving dan sesudah diberikan modul dengan nilai probabilitas (p) sebesar 0,000 lebih kecil dari 0,05. Menurut hasil uji Wilcoxon dapat disimpulkan bahwa modul berbasis problem solving efektif meningkatkan kemampuan analisis pada materi pencemaran lingkungan

\section{Daftar Pustaka}

Cabanilla-pedro, L. A., Acob-navales, M., \& Josue, F. T. (2013). Improving Analyzing Skills of Primary Students Using a Problem Solving Strategy. Juournal of Science And Mathematics Education In S.E Asia, 27(1), 33-53.

Chinedu, C., \& Kamin, Y. (2015). Strategies For Improving Higher Order Thinking Skills In Teaching And Learning Of Design And Technology Education. Journal of Technical Education and Training (JTET), 7(2), 35-43.

Fatonah, S., \& Prasetyo, Z. K. (2014). Buku Pembelajaran Sains. Yogyakarta: Ombak.

Gök, T., \& Sýlay, I. (2010). The Effects of Problem Solving Strategies on Students' Achievement, Attitude and Motivation. Latin-American Journal of Physics Education, 4(1), 7-21. Retrieved from http://dialnet.unirioja.es/servlet/arti culo? codigo $=3694877$

Hake, R. R. (1998). Interactive-engagement versus traditional methods: A sixthousand-student survey of 
mechanics test data for introductory physics courses. American Journal of Physics, 66(1), 64-74. https://doi.org/10.1119/1.18809

Hugerat, M., \& Kortam, N. (2014). Improving Higher Order Thinking Skills among Freshmen by Teaching Science through Inquiry. Eurasia Journal of Mathematics, Science \& Technology Education, 10(5), 447-454. https://doi.org/10.12973/eurasia.20 14.1107

Lestari, D. (2013). Penerapan Teori Bruner Untuk Meningkatkan Hasil Belajar Siswa Pada Pembelajaran Simetri Lipat di Kelas IV SDN 02 Makmur Jaya Kabupaten Mamuju Utara. Jurnal Kreatif Tadulako Online, 3(2), 129-141.

Maghfiroh, U. (2011). Penerapan Pembelajaran Fisika Bervisi Sets untuk Meningkatkan Kemampuan Berpikir Analitis Peserta Didik Kelas X. Jurnal Pendidikan Fisika Indonesia, 7, 6-12.

Mamu, H. D. (2014). Pengaruh Strategi Pembelajaran, Kemampuan Akademik dan Interaksinya terhadap Keterampilan Berpikir Kritis dan Hasil Belajar Kognitif IPA Biologi. Jurnal Pendidikan Sains, 2(1), 1-11.

Perveen, K. (2010). Effect of the problemsolving approach on academic achievement of students in mathematics at the secondary level. Contemporaty Isssues In Education Research, 3(3), 9-13.

Prayitno, Y. Y. (2013). Model Pembelajaran Problem Solving Bervisi SETS untuk Meningkatkan Pemahaman terhadap Kebencaanaan Alam dan Perpindahan Kalor serta Kemampuan Berpikir Kreatif Siswa. Semarang: Uiversitas Negeri Semarang.

Purnamasari, D., Suciati, \& Dwiastuti, S. (2016). Pengaruh Penerapan Media Augmented Reality Berbasis Discovery Learning terhadap Hasil
Belajar pada Materi Darah. BioPedagogi, 5(2), 7-14.

Risnawaty, Werdhiana, I. K., \& Amiruddin, H. (2016). Peningkatan Hasil Belajar IPA Fisika Dengan Menggunakan Model Pembelajaran Problem Solving Pada Siswa Kelas VII SMP Negeri 18 Palu. Jurnal Pendidikan Fisika Tadulako (JPFT), 3(3).

Sari, W. M., \& Sisiloningsih, E. (2015). Penerapan Model Assure Dengan Metode Problem Solving Untuk Meningkatkan Keterampilan Berpikir Kritis. Jurnal Inovasi Pendidikan Kimia, 9(1), 14681477.

Suhendri, H. (2012). Pengaruh Metode Pembelajaran Problem Solving Terhadap Hasil Belajar Matematika. Jurnal Formatif, 3(2), 105-114.

Suminto. (2015). Penerapan Model Pembelajaran Kooperatif Tipe Problem Solving pada Materi Pokok Lingkaran. Jurnal EDuMath, 1(1), 64-72.

Tajudin, N. M., \& Chinnappan, M. (2016). The Link between Higher Order Thinking Skills, Representatio https://doi.org/10.5642/jhummath.2 01301.08

Zannah, F. (2013). Keterampilan Berpikir Tingkat Tinggi Peserta Dididk SMA Pada Pembelajaran Konsep Protista Melalui Pendekatan Inkuiri Terbimbing. Pedagogik Jurnal Pendidikan, 8(2), 30-35 